\title{
Building Energy Efficiency in Nigeria Major Climatic Zones
}

\author{
K. M. Odunfa ${ }^{1 *}$, C. J. Nnakwe ${ }^{1}$, V. O. Odunfa ${ }^{2}$ \\ ${ }^{1}$ Mechanical Engineering Department, University of Ibadan, Ibadan, Nigeria \\ ${ }^{2}$ Estate Management Department, The Polytechnic Ibadan, Ibadan, Nigeria \\ Email: *odunfaj@yahoo.com
}

How to cite this paper: Odunfa, K.M., Nnakwe, C.J. and Odunfa, V.O. (2018) Building Energy Efficiency in Nigeria Major Climatic Zones. Journal of Building Construction and Planning Research, 6, 251-266.

https://doi.org/10.4236/jbcpr.2018.64017

Received: March 13, 2018

Accepted: November 18, 2018

Published: November 21, 2018

Copyright (C) 2018 by authors and Scientific Research Publishing Inc. This work is licensed under the Creative Commons Attribution International License (CC BY 4.0).

http://creativecommons.org/licenses/by/4.0/

\begin{abstract}
Energy consumption in both residential and public buildings has been established globally as been significantly high. The need to incorporate energy efficiency in building therefore becomes imperative in order to minimize the consumption level. This work therefore examines the effect of building orientation coupled with different building material composition on energy efficiency in building within major Nigeria climatic zones. The methodology adopted in this study entails carrying out a load survey and thereby calculating the cooling load required to condition the building space in two selected different orientations within the major Nigerian climatic zones. The standard cooling load equations were utilized in the evaluation of the various cooling loads. The selected locations considered within major Nigerian climatic zones are Ibadan in the South West, Jos in the middle belt and Maiduguri in the North East. The cooling load results obtained for the two different orientations are as follows; $151.45 \mathrm{~kW}$ and $163.17 \mathrm{~kW}$ for Ibadan, Maiduguri: 164 $\mathrm{kW}$ and $175.78 \mathrm{~kW}$, and $131.77 \mathrm{~kW}, 143.4 \mathrm{~kW}$ for Jos. The first orientation being North/South longitudinal placement of the building while the second orientation is East/West longitudinal placement respectively. The study established that the second orientation generated more cooling load. It is therefore concluded that the first orientation which is the North/South longitudinal placement of the building is best recommended. It also established the dependence of cooling load on the climatic condition of the building's location. Both building material compositions coupled with its orientation and climatic condition therefore play major significant role on the energy consumption in a building space.
\end{abstract}

\section{Keywords}

Orientation, Cooling Load, Thermal Storage, Material Composition, Load Survey 


\section{Introduction}

Energy consumption in both residential and tertiary buildings in developed and developing countries is significantly high. Although there are already existing standard energy efficiency methods, efforts through research are still being made in trying to proffer solutions and mitigate energy consumption in the building sector to the barest minimum. Energy efficiency in buildings is multi-faceted. On one hand, the utilization of renewable and wastes leads to self-energy sufficient buildings. It could be said that they are the best option for the environment. However, self-energy sufficient buildings need usually high-tech systems, which can be unfeasible from the economic point of view. The continuous extraction of raw materials and production of building materials and systems can also cause environmental pollution. On the other hand, the utilization of modern energy-efficient buildings called intelligent buildings comes to fore. The systems in the building are controlled to assure the proper management of the energy demand, to conserve energy, to improve the comfort levels including indoor-air quality and to increase the building's productivity through leveraging information. There has been an underlying global problem of insufficient energy production. The case of Nigeria is even worse, where the energy generated is far below the needed capacity, and yet much useful energy that is supposed to be conserved is being wasted or ill-utilized as a result of lack of government implemented policies and enlightenment programmes on the gains of adopting energy conservation measures on the environment and economic growth. It should be noted that, in the midst of the prevailing energy crisis in Nigeria, energy efficiency will play a pivotal role in ensuring access to energy. This study aims at investigating the load components of a building space and, subsequently analyzes the effects of building orientation and building material composition on the energy demand in buildings with in major Nigeria climatic zones.

\section{Literature Review}

Climatic design has been established as one of the best approaches to reduce the energy cost in buildings [1]. Proper design is the first step of defense against the stress of the climate. His findings revealed that buildings should be designed according to the climate of the site, reducing the need for mechanical heating or cooling. Hence maximum natural energy can be used for creating a pleasant environment inside the built envelope. He also investigated the effects of Natural ventilation as one of the requirements for low-energy building designs. According to his research, with the availability of inexpensive fossil energy and the tendency to provide better indoor environmental control, there has been a vast increase in the use of air-conditioning in new and refurbished buildings. However, recent scientific evidence on the impact of refrigerants and air-conditioning systems on the environment and the ability to building energy efficiency has promoted the more conscious building designers to give serious considerations to natural ventilation in non-domestic buildings. He noted that in the design of 
natural ventilation systems, the geographic location of the building should be considered. This will determine the seasonal variations in the external environmental parameters which include; air temperature, solar radiation, wind, humidity and outdoor air quality. He also found out that other considerations that could influence natural ventilation design are the exposure of the building to the wind, rain and the sun. However, buildings and other obstructions can distort the wind flow and adjacent buildings in particular could cause shielding from the wind, rain and the sun. Therefore, meteorological data should be adequate to take these effects into consideration.

The author also studied the relationship between climate, building and occupants. He proposed several different strategies; the cooling and the day-lighting strategy. The cooling strategy include five concepts; solar control (protection of the building from direct solar radiation); ventilation (expelling and replacing unwanted hot air); internal gains minimization (reducing heat from occupants, equipment and artificial lighting); external gains avoidance (protection from unwanted heat by infiltration or conduction through the envelope in hot climates); natural cooling (improving natural ventilation by acting on the external air in hot climates). The day-lighting strategy include four concepts; penetration (collection of natural light inside the building); distribution (homogeneous spreading of light into the spaces or focusing); protect (reducing by external shading devices the sun's rays penetration into the building); control (control light penetration by movable screens to avoid discomfort). His research aimed to provide a high level of building performance (BP), which could be defined as indoor environmental quality (IEQ), energy efficiency (EE) and cost efficiency (CE). Multi-criteria optimization of insulation options for warmth of buildings to increase energy efficiency investigated and established the enormous amount of energy consumed in existing buildings in Alipasino polje (Bosnia) [2]. The study also established that with an economic, environment and energy savings, the comfort and quality of life in buildings would be improved with extended life of buildings resulting by greater energy efficiency. Also, low heat transfer coefficient is necessary in order to decrease thermal losses in the buildings. His findings revealed that thermal insulation is carried out, by adding thermal insulation layer on the outer side of walls and only in exceptional cases inside of walls. The use of thermal insulation on the inside wall is physically weaker, although improved insulation value of the wall is achieved, significantly changing the heat flux in the wall and the main load-bearing wall becomes colder, resulting in the need for performing a vapor barrier to prevent the formation of condensate. Because of these shortcomings, he proposed that it is much better to use an external insulation of buildings. He also established that in the summer, building structures should not accumulate energy from the outside. The choice of materials must satisfy all regulations and calculations. The structure of energy consumption by different consumer groups in many countries is characterized by a high share of the residential and tertiary sector, which is very often responsible 
for a large percentage of the total final energy demand [3]. The research work established that for there to be a great potential for energy savings in the residential and tertiary sector, energy efficiency must be implemented. Apart from the traditional energy-saving measures, his findings revealed that standard energy efficiency methods should ensure a proper building envelope, good thermal wall properties, heating and electric systems operate under high efficiencies, heat recuperation or recovery. Additionally, thermal modernization of old buildings or buildings constructed recently but in poor thermal condition is performed to achieve significant reductions in energy consumption and to improve indoor-climate conditions. They are focused on the reduction of energy demand in buildings, which is mostly achieved by reduction of heat losses in local heat distribution systems and local heat sources, including the introduction of automation and control and in the total or partial exchange of heat sources. The potentials of energy saving and mitigation of greenhouse gas (GHG) emission offered by implementation of building energy efficiency policies in China was investigated [4]. The study established that implementing vigorous energy efficiency policies in buildings will play a significant role to the climate change mitigation both in China and in the world over the next 20 - 30 years. According to his research work, energy efficiency in buildings has long been regarded as a key component of energy security to reduce the energy dependence and energy bills for end-users since the outbreak of the first oil crisis in 1973. The international experiences show that an integrated policy should be formulated by combining the energy infrastructural quality, building energy efficiency and public policies. This will generate significant benefits given the fast growing urbanization process and the number of buildings that will be constructed in the nearest future. $\mathrm{He}$ was able to conclude that the development of more efficient building designs suitable for Chinese conditions, and more energy-efficient windows, building materials, envelope insulation and ventilation options create large opportunities to save energy in the near future and over a long term since buildings can last for over 40 years. Joshua Kneifel [5] investigated the life-cycle carbon and cost analysis of energy efficiency measures in new commercial buildings. He was able to estimate the life-cycle energy savings, carbon emission reduction, and cost effectiveness of energy efficiency measures in new commercial buildings using an integrated design approach, and estimated the implications from a cost on energy-based carbon emissions. After he simulated energy consumption and building cost databases; the life-cycle cost effectiveness and carbon emissions of each design were determined. His findings revealed that conventional energy efficiency technologies such as thermal insulation, low-emissivity windows, window overhangs, and day-lighting controls which can be used to decrease energy use in new commercial buildings by $20 \%-30 \%$ on average and up to over $40 \%$ for some building types and locations. He was able to establish that, although increasing energy efficiency usually increases the first costs of a building, the energy savings over the service life of the building often offset these initial higher costs. The first 
costs can be lower for the more efficient building design because, through integrated design, the improved efficiency reduces the size of the heating and/or cooling system required to meet the peak heating and/or cooling loads. K. Bilen [6] research paper highlighted the general gains on the economy of a country, when energy efficiency policies are adopted. His finding showed that, about $70 \%$ of the total worldwide primary energy used is lost throughout the energy supply chain, starting with the production and transport of energy all the way to its final consumption. He was therefore able to establish that without clearly improving energy efficiency, the aims of sustainable energy management and a successful climate protection policy cannot be reached. He also established that there are many ways to use energy more efficiently. His findings also exposed that energy efficiency is a particular concern of developing countries. On the one hand, there are many outdated power plants in these countries. With just a little extra input, such as an upgrade of the turbines, their energy efficiency can be clearly improved. On the other hand many developing countries are faced with the question of how to meet the increasing energy needs of the population.

Effect of building orientation on energy conservation was investigated by Odunfa K.M. et al. [7], it was established that one vital way of conserving energy is through appropriate orientation of building. The orientation of a building is often determined by the site topography and/or location. His research methodology entailed basically a thorough assessment of the energy requirements of buildings. He estimated the cooling load required for the building space, when the buildings were placed in two different orientations. The orientations considered are when the building length is facing the east/west direction and when it is facing the north/south direction. His findings revealed that from the first orientation when the building length is facing the east/west direction shows a refrigeration capacity of 63.3 Tonnage and the second orientation when he building length is facing the north/south direction gave a refrigeration tonnage of 60.6 tonnages. His results show that the north/south orientation of the building length is the recommended orientation. He also carried out a survey in Ibadan, Nigeria on the amount of buildings that conformed to the proper orientation of the length of buildings facing the north/south direction. His findings shows that as a result of lack of necessary information, ill awareness and campaign by the appropriate authorities, improper town planning, and poverty, houses were built without due regard to the proper orientation and thus energy conservation. His research basically aimed as to provide education and enlightenment for the general public, which may hopefully lead to improved energy conservation or efficiency. P.A. Nwofe [8] research paper, on the need for energy efficient buildings in Nigeria, studied the integration of solar passive designs with solar architecture for increased energy efficiency in buildings to achieve maximum comfort, reduced green house gases and reduced energy cost. He established that the use of mechanical devices to achieve thermal comfort is not only capital intensive, but also produces green house gases. Solar architecture 
ensures that the building utilizes natural concepts to achieve comfort in buildings without artificial devices. He integrated the solar passive technology into energy efficient building materials, to ensure that maximum comfort is attained with reduced energy cost in buildings. He also established that solar passive buildings are designed to either enable buildings gain as much heat as possible or loose heat, depending on the prevailing climatic conditions. His findings revealed ways for direct passive cooling in buildings. He established that direct cooling include ventilation, infiltration and air vents while indirect cooling involved evaporative cooling and shading. He established that a high performing building envelope is achieved through a proper insulation, elimination of thermal bridges and air tight constructions. He also established that bioclimatic architecture is achieved by proper shape and orientation of buildings, passive solar systems, and solar protection.

Sunday Oyedepo [9] in his research work on energy for sustainable development in Nigeria, pointed out that about $90 \%$ of the world energy supplies are provided by fossil fuels, with the associated emissions causing local, regional and global environmental problems. His findings shows that the current energy projections and expected future global energy demand patterns are not sustainable.

\section{Nigeria Climatic Zones}

Nigeria is a country in the Western region of the African continent; Noted geographical features in include the Adamawa highlands, Mambilla Plateau, Jos Plateau, Obudu Plateau, the Niger River, River Benue and Niger Delta. Nigeria's geographical coordinates are $10^{\circ} 00^{\prime} \mathrm{N}, 8^{\circ} 00^{\prime} \mathrm{E}$. Although Nigeria is a tropical country, there exists a wide climatic variation in different parts. Near the coastline, temperatures are usually below $32^{\circ} \mathrm{C}\left(90^{\circ} \mathrm{F}\right)$, but the air is humid at night. Inland, there exists two seasons, a wet season from April to October with usually lower temperatures and a dry season from November to March, with a temperature range of $38^{\circ} \mathrm{C}$ to $12^{\circ} \mathrm{C}$ Nigeria is affected by four climate types; these climate types are distinguishable, as one transcends from the southern part of $\mathrm{Ni}$ geria to the northern part through the middle belt. Nigeria, like the rest of West Africa and other tropical lands, has only two seasons. These are the dry and the rainy season. The dry season being accompanied by a dust laden air-mass from the Sahara desert, locally known as harmattan and the rainy season is heavily influenced by an air-mass originating from the South Atlantic Ocean, locally known as the south west wind. Temperatures in Nigeria vary according to the seasons. Around March to April following the onset of the rainy season, temperatures can go as high as $44^{\circ} \mathrm{C}\left(111.2^{\circ} \mathrm{F}\right)$ in some parts of Nigeria. Semi temperate weather conditions prevail on the highlands in Central Nigeria at an altitude of 1217 meters (3993 ft) above sea level, namely the Jos Plateau. Average monthly temperatures in the Jos plateau ranges between $21^{\circ} \mathrm{C}$ to $25^{\circ} \mathrm{C}\left(70^{\circ} \mathrm{F}-77^{\circ} \mathrm{F}\right)$, and from mid-November to late January, night time temperatures drop as low as $11^{\circ} \mathrm{C}\left(52^{\circ} \mathrm{F}\right)$. Jos receives about 1400 millimetres ( 55 inches) of rainfall annually. 
The city of Ibadan has a tropical wet and dry climate, with a lengthy wet season and relatively constant temperatures throughout the course of the year. Ibadan's wet season runs from March through October, while the dry season runs from November to February. The mean total rainfall for Ibadan is $1420.06 \mathrm{~mm}$, mean maximum temperature is $26.46^{\circ} \mathrm{C}$, minimum $21.42^{\circ} \mathrm{C}$ and the relative humidity is $74.55 \%$. The definition of climatic zones for architectural designs stems from the fact that climatic conditions and hence the requirements for thermal comfort are the basis for the selection of building form and building elements such as size of windows, insulation value of roofs and walls, the capacity of the air-conditioning equipment to be installed and the building orientation. It is therefore possible, to determine the approximate boundaries where a change in the climate and a change in thermal comfort requirements should be reflected in changed building form or changed building elements. These boundaries will effectively define the climatic zones for architectural design. The major climatic zones to be considered in this research study include, the tropical rainforest zone (parts of southern Nigeria), where the annual rainfall is between 60 to 80 inches (1524 to $2032 \mathrm{~mm}$ ), the savannah zone (the middle belt), where the annual rainfall is between 20 to 60 inches ( 508 to $1524 \mathrm{~mm}$ ) and the Arid zone (parts of northern Nigeria), where the annual rainfall is less than 20 inches (508 $\mathrm{mm}$ ) per year. The major cities in these various Nigerian climatic zones to be studied are Ibadan, Maiduguri and Jos. Their locations lying in different climatic zones have been identified as shown in the map below in Figure 1.

\section{Design Procedures}

In cooling load analysis in building, the followings are always taken into consideration; building characteristics, building location, orientation and external shading, weather data and selection of outdoor design conditions, selection of indoor design condition, indoor dry-bulb temperature, indoor wet-bulb temperature and ventilation rate, lighting, occupants, internal equipment, appliance and processes coupled with finally selection of the design level. For cooling load analysis in building, the following procedures as developed by the American Society of Heating, Refrigeration and Air-conditioning Engineers (ASHRAE) [10] and Norman [11] are employed. The procedures are hereby itemized as follows:

Building sunlight heat gain:

This includes the sunlight heat gains through the glass, the walls and the roof.

Building transmission heat gain:

This is the transmission heat gain through the glass and the appropriate building walls.

Infiltration heat gain:

This is the infiltration heat gain through the wall, door and window crack length.

Outside air by pass heat load:

This is the outside by-pass heat load through the ventilation and air conditioning 


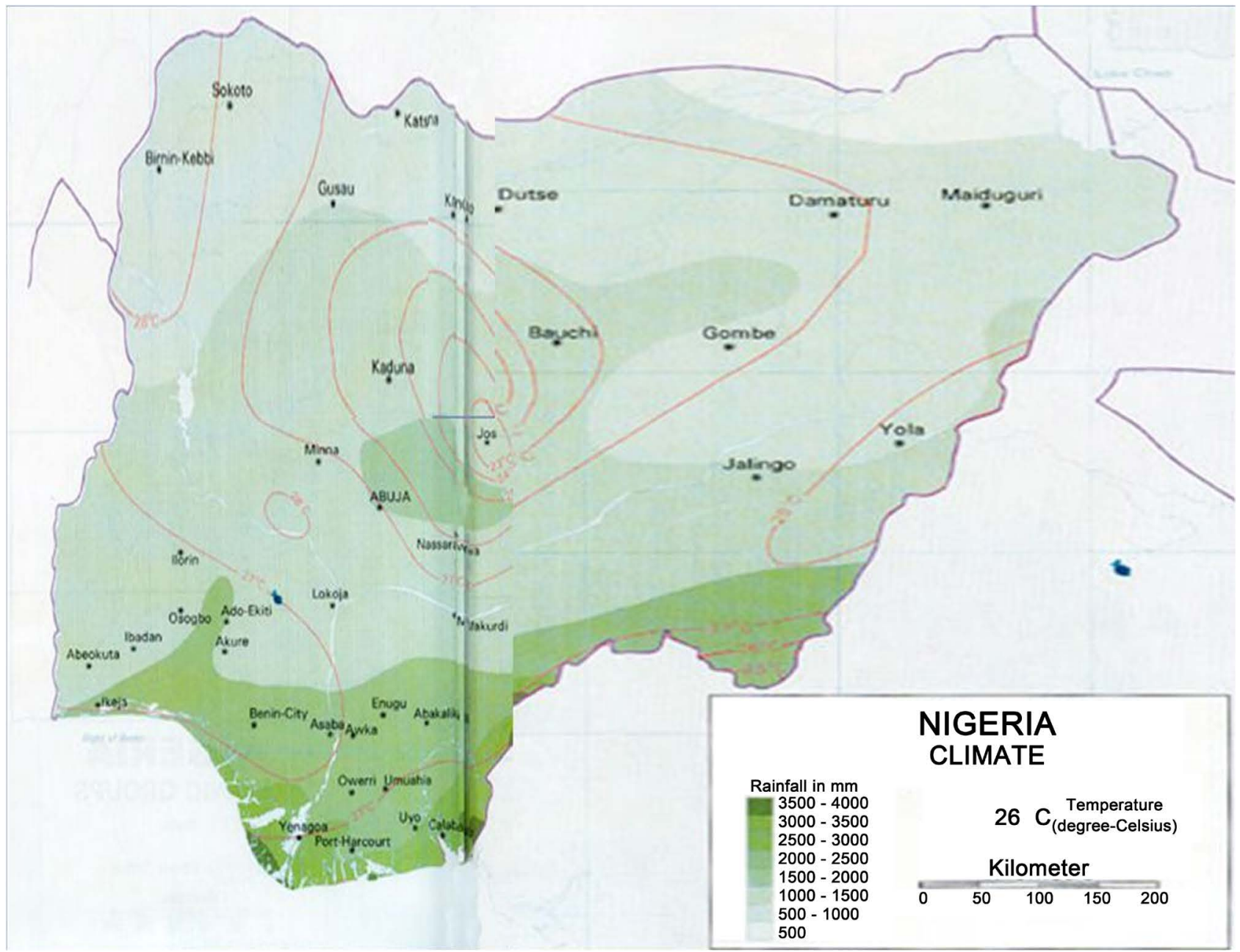

Figure 1. Map of Nigeria showing the climatic.

equipment bypass factor.

\section{Internal heat load:}

This load is generated by the occupants, machines, equipment, lighting fittings and any other heat generating devices inside the building.

Room latent heat:

These are the heat loads released by the occupants through infiltration and ventilation of the building.

The load is generated through the outside ventilation air and air-conditioning equipment bypass factor.

\section{Cooling load classification with equations}

Two ways of classifying the building cooling load are External and Internal loads classification. The classes are as follow with their equations:

External loads

1) Opaque elements located above ground (walls, roofs and doors) $q_{s}=U * A * C L T D$.

2) Convective transfer through transparent assemblies (windows):

$q_{s}=U^{*} A^{*} C L T D$. 
3) Radioactive transfer through transparent assemblies (window):

$q_{s}=A^{*} S C^{*} S H E^{*} C L F$.

4) Ventilation and Infiltration air (sensible): $q_{s}=1.08 * C F M * \Delta T$.

5) Ventilation heat load (latent): $q_{L}=C F M^{*} \Delta W^{*} B F^{*} 0.68$.

6) Infiltration heat load (latent): $q_{L}=C F M * \Delta W^{*} 0.68$.

\section{Internal loads}

1) Lighting systems: $q_{s}=$ inputlampwattage $* 3.41 * C L F$.

2) People: a) sensible: $q_{s}=N * S H R$

b) Latent: $q_{L}=N^{*} L H R$.

3) Equipment and appliances:

a) Sensible: $q_{s}=$ installedwattage $* C L F * 3.41$

b) Latent: $q_{L}=$ installedwattage $*$ clf $* 3.41$.

4) Motor heat load: $q_{s}=M . H * 2546 * M E$.

Grand total heat and refrigerator tonnage: By taking the sum of both external and internal heat loads, gives the grand total heat load of the space, Btu/h. The refrigeration load, tons, is gotten from (grand-total heat, Btu/h) $(12,000$ Btu/(h.Ton) (3577 W) of refrigeration).

\section{Design Case Study}

\section{Introduction}

The design case study is the Faculty of Technology Lecture Theatre, University of Ibadan, Nigeria Figures 2-4 [7]. It has an estimated capacity of 520 people. This type of Lecture Theatre is to be located in three major cities located in major Nigerian climatic zones hence cooling load analysis for this particular building structure is to be calculated within the major climatic zones. The selected cities are Ibadan, Abuja and Maiduguri. The cooling load analysis is to be carried out, in other to select the proper air conditioning equipment capacity, and thereby ensure a minimum energy use in the lecture theatre. The building structure is to be orientated in different directions in the course of our analysis in other to the compare the building orientation that will require a lesser air-conditioning equipment capacity; and thereby be able to advice and enlighten building engineers and consultants on the gains of adopting energy efficiency.

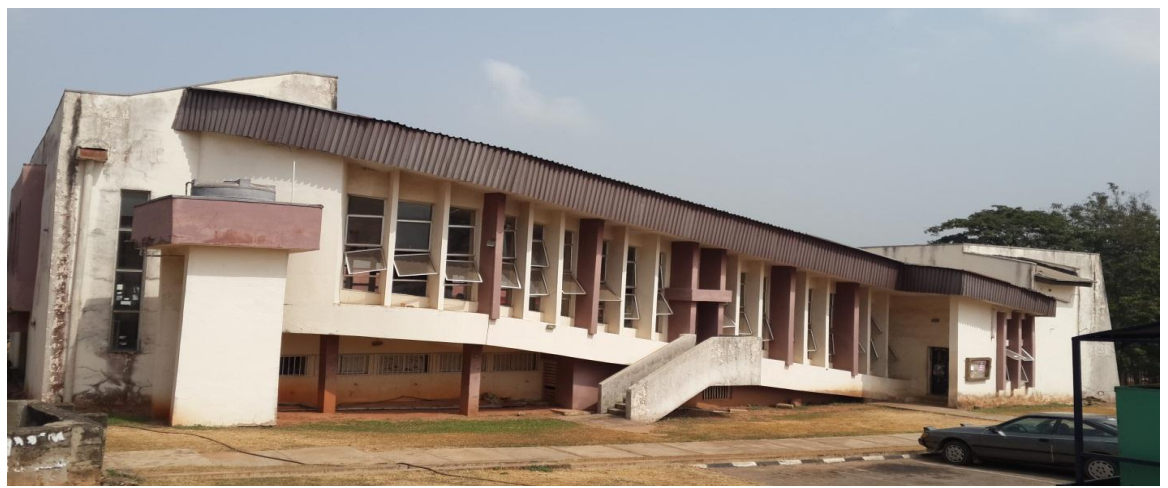

Figure 2. Building complex of the Faculty of Technology Lecture theatre (South elevation). 


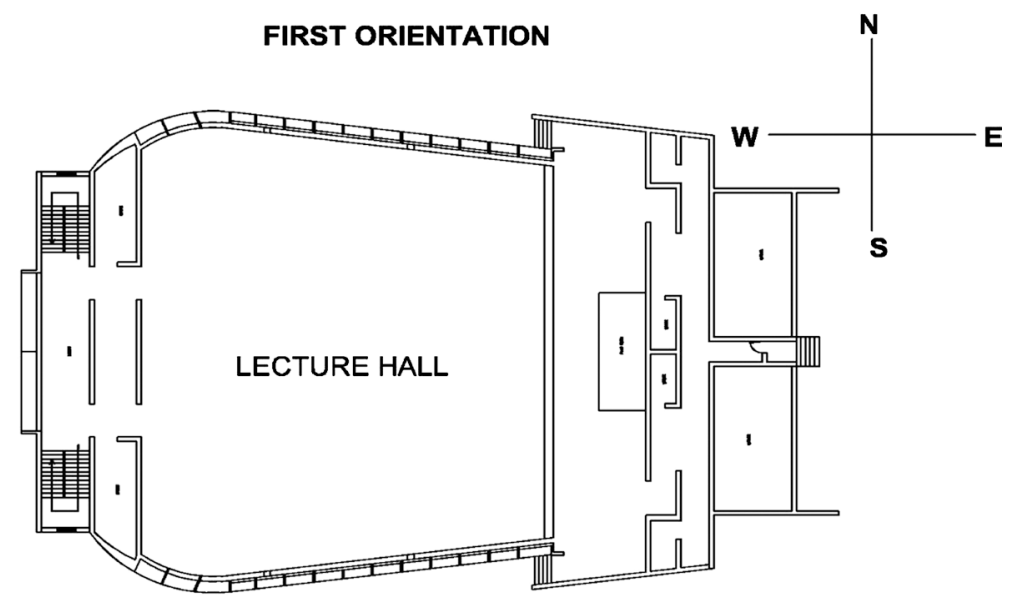

\section{FLOOR PLAN OF THE FACULTY OF TECHNOLOGY LECTURE THEATRE}

Figure 3. Floor plan of the Faculty of Technology Lecture theatre (first orientation) cardinal points showing the direction of true north.

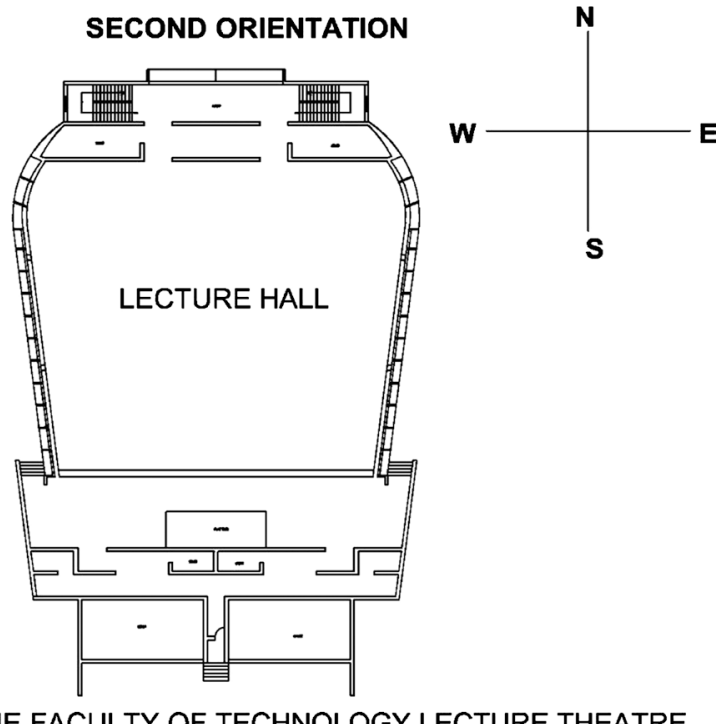

FLOOR PLAN OF THE FACULTY OF TECHNOLOGY LECTURE THEATRE

Figure 4. Floor plan of the Faculty of Technology Lecture theatre (second orientation) cardinal points showing the direction of true north.

\section{Design Assumptions}

1) In this study the first orientation assumes the short and shaded side of the building is facing the East/West direction and the longer part facing the north/south direction (North/South longitudinal placement), while the second orientation assumes the short and shaded side of the building facing the north/south direction and the longer side facing the east/side direction (East/West longitudinal placement).

2) The roof is assumed to be a patch roof made of sheet metal, with a heat transfer coefficient, $\mathrm{U}$ of $0.27 \mathrm{Btu} / \mathrm{h} \cdot \mathrm{ft}^{2}{ }^{2 .} \mathrm{F}$, and insulated on the inside with suspended ceiling and it is directly facing the sun.

3) The glass window is assumed to be double hung and always closed with a 
crack-length of $726 \mathrm{ft}$ and a heat transfer coefficient of $1.13 \mathrm{Btu} / \mathrm{h} . \mathrm{ft}^{2.0} \mathrm{~F}$.

4) The wall type is under the Group D category. It is made of a 4-in hollow block, with a weight of $90 \mathrm{lb} / \mathrm{ft}^{2}$ and a heat transfer coefficient of $0.45 \mathrm{Btu} / \mathrm{h} \cdot \mathrm{ft}^{2.0} \mathrm{~F}$. It has a $5 / 8$ plaster and is painted on both the inside and outside.

\section{Results}

The results of the cooling load estimated when the building length is facing the east/west direction and when it is facing the north/south direction, and also the results when a different wall type is used, is as shown in a Tables 1-4. The amount of energy conserved in both cases in the two different orientations is

Table 1. First orientation.

\begin{tabular}{cccc}
\hline First Orientation & IBADAN & MAIDUGURI & JOS \\
\hline Sunlight Heat Gain & $117,247.2$ & $132,608.24$ & $99,427.68$ \\
Transmission Heat Gain & 7322.4 & $10,576.8$ & 813.6 \\
Infiltration Heat Gain & 5292.54 & 7644.78 & 588.06 \\
Outside Air Bypass Heat Load & 7020 & 10,140 & 780 \\
Heat Load from Internal Sources & $160,088.44$ & $160,088.44$ & $160,088.44$ \\
\hline Total Room Sensible Heat & $296,970.58$ & $321,056.22$ & $261,697.78$ \\
Total Room Latent Heat & $248,410.56$ & $259,218.58$ & $235,801.32$ \\
Total Outside Air Heat & $30,326.4$ & $43,804.8$ & 3369.6 \\
\hline Grand Total Heat Load & $575,707.54$ & $624,079.6$ & $500,868.7$ \\
\hline Refrigeration Load & 47.97 & 52.01 & 41.74 \\
\hline KILOWATT & 151.45 & 164.18 & 131.77
\end{tabular}

All parameters are in Btu/hr unless stated otherwise.

Table 2. Second orientation.

\begin{tabular}{cccc}
\hline Second Orientation & IBADAN & MAIDUGURI & JOS \\
Sunlight Heat Gain & $161,781.615$ & $176,682.615$ & $143,761.455$ \\
Transmission Heat Gain & 7322.4 & $10,576.8$ & 813.6 \\
Infiltration Heat Gain & 5292.54 & 7644.78 & 588.06 \\
Outside Air Bypass Heat Load & 7020 & 10,140 & 780 \\
Heat Load from Internal Sources & $160,088.44$ & $160,088.44$ & $160,088.44$ \\
\hline Total Room Sensible Heat & $341,504.995$ & $365,132.635$ & $306,031.555$ \\
Total Room Latent Heat & $248,410.56$ & $259,218.58$ & $235,801.32$ \\
Total Outside Air Heat & $30,326.4$ & $43,804.18$ & 3369.6 \\
\hline Grand Total Heat Load & $620,241.955$ & $668,155.395$ & $545,202.475$ \\
\hline TONNS & 51.68 & 55.67 & 45.43 \\
\hline KILOWATT & 163.17 & 175.78 & 143.4 \\
\hline
\end{tabular}

All parameters are in $\mathrm{Btu} / \mathrm{hr}$ unless stated otherwise. 
Table 3. First orientation.

\begin{tabular}{cccc}
\hline First Orientation & IBADAN & MAIDUGURI & JOS \\
\hline Sunlight Heat Gain & $115,290.45$ & $129,330.65$ & $99,210.05$ \\
Transmission Heat Gain & 7322.4 & $10,576.8$ & 813.6 \\
Infiltration Heat Gain & 5292.54 & 7644.78 & 588.06 \\
Outside Air Bypass Heat Load & 7020 & 10,140 & 780 \\
Heat Load from Internal Sources & $160,088.44$ & $160,088.44$ & $160,088.44$ \\
\hline Total Room Sensible Heat & $295,013.83$ & $317,780.67$ & $261,480.15$ \\
Total Room Latent Heat & $248,410.56$ & $259,218.58$ & 235801.32 \\
Total Outside Air Heat & $30,326.4$ & $43,804.8$ & 3369.6 \\
\hline Grand Total Heat Load & $573,750.79$ & $620,804.05$ & $500,651.07$ \\
\hline TONNS & 47.81 & 51.73 & 41.72 \\
\hline KILOWhigeration Load & 150.94 & 163.32 & 131.71 \\
\hline
\end{tabular}

All parameters are in Btu/hr unless stated otherwise.

Table 4. Second orientation.

\begin{tabular}{cccc}
\hline Second Orientation & IBADAN & MAIDUGURI & JOS \\
\hline Sunlight Heat Gain & $156,724.415$ & $170,764.615$ & $140,425.855$ \\
Transmission Heat Gain & 7322.4 & $10,576.8$ & 813.6 \\
Infiltration Heat Gain & 5292.54 & 7644.78 & 588.06 \\
Outside Air Bypass Heat Load & 7020 & 10,140 & 780 \\
Heat Load from Internal Sources & $160,088.44$ & $160,088.44$ & $160,088.44$ \\
\hline Total Room Sensible Heat & $336,447.795$ & $359,217.635$ & $302,695.955$ \\
Total Room Latent Heat & $248,410.56$ & $259,218.58$ & $235,801.32$ \\
Total Outside Air Heat & $30,326.4$ & $43,804.18$ & 3369.6 \\
\hline Grand Total Heat Load & $615,184.755$ & $662,237.395$ & $541,866.875$ \\
\hline TONNS & 51.26 & 55.18 & 45.16 \\
\hline Kefrigeration Load & 161.84 & 174.22 & 142.56 \\
\hline
\end{tabular}

All parameters are in $\mathrm{Btu} / \mathrm{hr}$ unless stated otherwise.

also shown. Table 5 and Table 6 below shows the summarized cooling load for the building space in the two different orientations and also the effects of building material composition on energy efficiency while Tables 7-9 show the electrical energy conserved.

\section{Discussions}

From Table 5, it can be deduced that the cooling load estimated for the two different orientation of the building considered have differing values. From the foregoing results, it was seen that the first orientation of the building, that is when the building length is in the north/south direction, produces the lesser 
Table 5. Cooling load in different orientations.

\begin{tabular}{cccc}
\hline \multirow{2}{*}{ LOCATION } & ORIENTATION & \multicolumn{2}{c}{ REFRIGERATION LOAD } \\
\cline { 3 - 4 } & & TONNAGE(TONNS) & KILOWATT(KW) \\
\hline \multirow{2}{*}{ IBADAN } & FIRST & 47.97 & 151.45 \\
& SECOND & 51.68 & 163.17 \\
MAIDUGURI & FIRST & 52 & 164 \\
& SECOND & 55.67 & 175.78 \\
JOS & FIRST & 41.73 & 131.77 \\
& SECOND & 45.43 & 143.4 \\
\hline
\end{tabular}

Table 6. Summarized cooling load in the two different orientations.

\begin{tabular}{cccccccc}
\hline \multicolumn{7}{c}{ ORIENTATION } \\
\hline \multirow{2}{*}{ FIRST(HEAT LOAD) } \\
\cline { 2 - 7 } & BTU/HR & TONN-AGE & $\begin{array}{c}\text { ELECTRI-CAL } \\
\text { ENERGY(KW) }\end{array}$ & BTU/HR & TONN-AGE $\begin{array}{c}\text { ELECTRI-CAL } \\
\text { ENERGY(KW) }\end{array}$ & $\begin{array}{c}\text { ELECTRICALENERGY } \\
\text { CONSERVED (KW) }\end{array}$ \\
\hline IBADAN & $575,707.54$ & 47.97 & 151.45 & $620,241.955$ & 51.68 & 163.17 & 11.72 \\
MAI-DUGURI & $624,079.6$ & 52.01 & 164.18 & $668,155.395$ & 55.67 & 175.78 & 11.6 \\
JOS & $500,868.7$ & 41.74 & 131.77 & $545,202.475$ & 45.43 & 141.4 & 9.63 \\
\hline
\end{tabular}

Table 7. Summarized cooling load in the two different orientations.

\begin{tabular}{|c|c|c|c|c|c|c|c|}
\hline \multicolumn{8}{|c|}{ ORIENTATION } \\
\hline \multirow[b]{2}{*}{ LOCATION } & \multicolumn{3}{|c|}{ FIRST(HEAT LOAD) } & \multicolumn{3}{|c|}{ SECOND(HEAT LOAD) } & \multirow{2}{*}{$\begin{array}{c}\text { ELECTRICALENER } \\
\text { GY CONSERVED } \\
(\mathrm{KW})\end{array}$} \\
\hline & BTU/HR & TONN-AGE & $\begin{array}{l}\text { ELECTRI-CAL } \\
\text { ENERGY(KW) }\end{array}$ & $\mathrm{BTU} / \mathrm{HR}$ & TONN-AGE & $\begin{array}{l}\text { ELECTRI-CAL } \\
\text { ENERGY(KW) }\end{array}$ & \\
\hline IBADAN & $575,707.54$ & 47.97 & 151.45 & $620,241.955$ & 51.68 & 163.17 & 11.72 \\
\hline MAI-DUGURI & $624,079.6$ & 52.01 & 164.18 & $668,155.395$ & 55.67 & 175.78 & 11.6 \\
\hline JOS & $500,868.7$ & 41.74 & 131.77 & $545,202.475$ & 45.43 & 141.4 & 9.63 \\
\hline
\end{tabular}

Table 8. Summarized cooling load in the two different orientations, when a brick masonry wall is used.

\begin{tabular}{cccccccc}
\hline & \multicolumn{7}{c}{ ORIENTATION } \\
\hline \multirow{2}{*}{ LIRST(HEAT LOAD) } & \multicolumn{3}{c}{ SECOND(HEAT LOAD) } \\
\cline { 2 - 7 } & BTU/HR & TONN-AGE & $\begin{array}{c}\text { ELECTRI-CAL } \\
\text { ENERGY(KW) }\end{array}$ & BTU/HR & TONN-AGE & $\begin{array}{c}\text { ELECTRI-CALENE } \\
\text { RGY(kw) }\end{array}$ & $\begin{array}{c}\text { ELECTRI-CALENERGY } \\
\text { CONSER-VED(KW) }\end{array}$ \\
\hline $\begin{array}{c}\text { IBA-DAN } \\
\text { MAI-DUG-UR } \\
\text { I }\end{array}$ & 573,75079 & 47.81 & 150.94 & $615,184.755$ & 51.26 & 161.84 & 10.9 \\
JOS & $520,808.05$ & 51.73 & 163.32 & $662,237.395$ & 55.18 & 174.22 & 10.9 \\
\hline
\end{tabular}


cooling load. The higher values gotten when the building was reoriented is as a result of a larger and longer area of the building construction now facing the direction of the sun. The disparity in the values gotten from both orientations is understandable, since of all the factors that can affect the cooling load of a building space, the orientation of the building contributes the greatest amount This is the major reason why a proper building orientation should be adopted, with respect to the direction of the sun, in other for energy to be duly conserved. The electrical energy conserved as a result of the building orientation is demonstrated in Table 7. Also, from Table 6, it can be seen that when a brick masonry wall construction is used, there was a reduction in the refrigeration load as compared to when normal regular block is used for the building wall construction. Table 8, shows the electrical energy conserved when a brick masonry wall construction is utilized in the two orientations. Table 9 compares the cooling load and the subsequent electrical energy conserved in kilowatts, when a brick masonry wall and a regular hollow block is used for the building wall construction.

From the line graph shown in Chart 1 and Chart 2, it can be seen that the

Table 9. Comparing the electrical energy conserved in the two different orientations, when regular block and brick masonry block type is used.

\begin{tabular}{|c|c|c|c|c|}
\hline LOCATION & ORIENTATION & $\begin{array}{l}\text { REFRIGERATION LOAD (KW) } \\
\text { (REGULAR BLOCK) }\end{array}$ & $\begin{array}{l}\text { REFRIGERATION LOAD (KW) } \\
\text { (BRICK MASONRY) }\end{array}$ & $\begin{array}{l}\text { ELECTRI-CAL ENERGY } \\
\text { CONSER-VED(KW) }\end{array}$ \\
\hline \multirow{2}{*}{ IBADAN } & FIRST & 151.45 & 150 & 1.45 \\
\hline & SECOND & 163.17 & 161.84 & 1.33 \\
\hline \multirow{2}{*}{ MAIDUGURI } & FIRST & 164 & 163.22 & 0.78 \\
\hline & SECOND & 175.78 & 174.22 & 1.56 \\
\hline \multirow{2}{*}{ JOS } & FIRST & 131.77 & 131.71 & 0.06 \\
\hline & SECOND & 143.4 & 142.55 & 0.85 \\
\hline
\end{tabular}

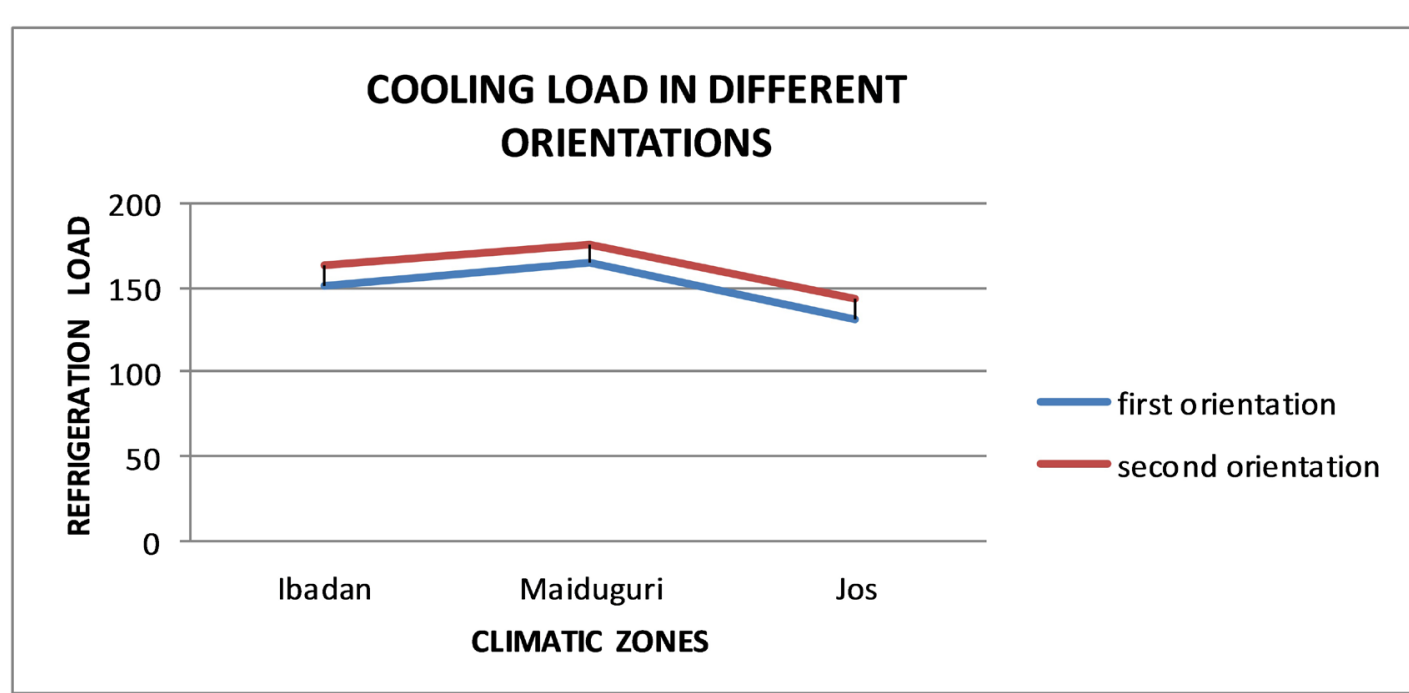

Chart 1. Cooling load in the two different orientations in Nigeria major climatic zones. 


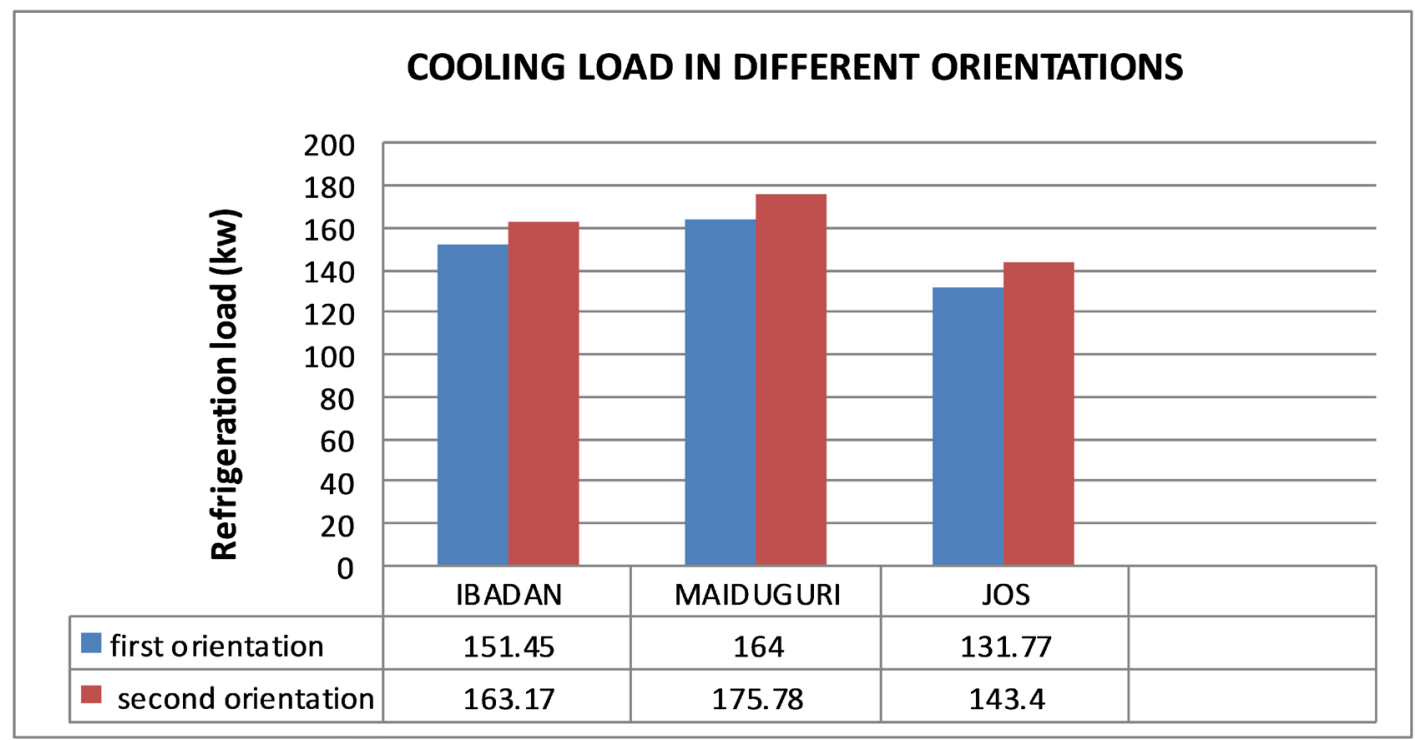

Chart 2. Cooling load estimates in the two different orientations in major Nigerian climatic zones.

cooling load decreases from the arid zone (Maiduguri) to the tropical rainforest zone (Ibadan) and the savannah zone (Jos). The cooling load in Jos is lower than the others because of the higher elevation, the higher air moisture content level or specific humidity and the cold and temperate weather. The cooling load in Maiduguri is larger because of the dry, hot and more tropical climate (equatorial) prevalent in most northern states in Nigeria, as compared to the south.

\section{Conclusion}

This work has fully and successfully examined the effects of building orientation on energy efficiency in a building. Buildings should be constructed and equipment selection and installation made according to the climate of the place. The results obtained from this research work will be able to provide information, enlightenment and advice to both private individuals, government institutions, building engineers and consultants coupled with the facility managers on the importance of adopting energy efficiency and how electrical energy could be saved up when energy efficiency policies are adopted. Presently, the current status of Nigerian building performance generally does not conform to the outcome result of my study, and in fact it is just the opposite when talking about the rural settlement areas.

\section{Conflicts of Interest}

The authors declare no conflicts of interest regarding the publication of this paper.

\section{References}

[1] Abdeen, M.O. (2008) Renewable Building Energy Systems and Passive Human Comfort Solutions. Renewable and Sustainable Energy Reviews, 12, 1562-1587. https://doi.org/10.1016/j.rser.2006.07.010 
[2] Adnan, C. and Branko, V. (2014) Multi-Criteria Optimization of Insulation Options for Warmth of Buildings to Increase Energy Efficiency. Procedia Engineering, 69, 911-920. https://doi.org/10.1016/j.proeng.2014.03.070

[3] Dorota, C. (2003) Towards Sustainable-Energy Buildings. Applied Energy, 76, 211-217. https://doi.org/10.1016/S0306-2619(03)00059-X

[4] Jun, L. (2008) Towards a Low-Carbon Future in China's Building Sector. A Review of Energy and Climate Models Forecast. Energy Policy, 36, 1736-1747. https://doi.org/10.1016/j.enpol.2008.01.029

[5] Joshua, K. (2010) A Life-Cycle Carbon and Cost Analysis of Energy Efficiency Measures in New Commercial Buildings. Energy and Buildings, 42, 333-340. https://doi.org/10.1016/j.enbuild.2009.09.011

[6] Bilen, K., et al. (2008) Energy Production, Consumption and Environmental Pollution for Sustainable Development. A Case Study in Turkey. Energy Reviews, 12, 1529-1561.

[7] Odunfa, K.M., Ojo, T.O., Odunfa, V.O. and Ohunakin, O.O. (2015) Energy Efficiency in Building: Case Study of Buildings at the University of Ibadan, Nigeria. Building Construction and Planning Research, 3, 18-26.

https://doi.org/10.4236/jbcpr.2015.31003

[8] Nwofe, P.A. (2014) Need for Energy Efficient Buildings in Nigeria. International Journal of Energy and Environmental Research, 2, 1-9.

[9] Oyedepo, S.O. (2012) Energy Efficiency and Conservation Measures: Tools for Sustainable Energy Development in Nigeria. An International Journal of Energy Engineering, 2, 86-98.

[10] ASHRAE (1985) ASHRAE Handbook 1985 Fundamentals. American Society of Heating, Refrigerating and Air-Conditioning Engineers Inc., Atlanta.

[11] Norman, C.H. (1984) Modern Air-Conditioning Practice. McGraw Hill Inc., New York. 